\title{
Association between the use of a baby's bottle and pacifier and the absence of breastfeeding in the second six months of life
}

Renata Ribeiro Rigotti ${ }^{1}$

Maria Inês Couto de Oliveira ${ }^{2}$

Cristiano Siqueira Boccolini ${ }^{3}$

${ }^{1}$ Programa de PósGraduação em Saúde Coletiva, Universidade Federal Fluminense. Rua Marquês do Paraná 303, $4^{\circ}$ andar, prédio anexo ao HUAP. 24033-900. Niteró RJ Brasil. renata.rrigotti@ gmail.com

${ }^{2}$ Departamento de Epidemiologia e Bioestatística, Instituto de Saúde Coletiva, Universidade Federal Fluminense.

${ }^{3}$ Departamento de Nutrição Social, Instituto de Nutrição, Universidade Estadual do Rio de Janeiro.

\begin{abstract}
Introduction: The World Health Organization recommends breastfeeding for two years or more and advises against bottle feeding and pacifier use. Objective: Investigate the association between bottle feeding and pacifier use, and breastfeeding in the second half-year of life. Methods: Survey in a municipality of Rio de Janeiro state, in 2006, interviewing those responsible for 580 children aged 6-11 months. Bottle feeding and pacifier use, and variables which in the bivariate analysis were associated with the outcome 'absence of breastfeeding' $(\geq 0.20)$, were selected for multiple analysis. Adjusted prevalence ratios were obtained by a Poisson regression model. Results: $40 \%$ of the children 6-11 months were not being breastfed, 47\% used a pacifier and 57\% used a bottle. Pacifier use (PR = 3.245; CI95\%: 2.4904.228) and bottle feeding ( $P R=1.605$; CI95\%: 1.273-2.023) were shown to be strongly associated with the outcome, and also with: mother's low schooling ( $P R=0.826$; CI95\%: 0.689-0.990); low birth weight $(P R=1.488$; CI95\%: 1.159-1.910); mother not being the baby carer $(P R=1.324$; CI95\%: 1.080-1.622); and increasing age of the baby in days ( $P R=1.004$; CI95\%: 1.002-1.006). Conclusions: The use of pacifiers and bottles can reduce continued breastfeeding. Stronger discouragement of these artifacts should be adopted in public health policies.
\end{abstract}

Key words Breastfeeding, Bottle, Pacifiers, Infant nutrition, Epidemiological studies 


\section{Introduction}

There is a great deal of scientific evidence about the advantages of breastfeeding, both from the nutritional point of view - since mothers' milk contains the components that are appropriate and have the ideal bioavailability for growth of the child - and also from the point of view of the protection that the species-specific nature of human milk confers ${ }^{1}$.

A trend to increased breast feeding has been observed in Brazil, which has been the result of public policies implemented in the last three decades, such as the Brazilian Standards for Sales of Foods to Nursing Children, (Norma Brasileira de Comercialização de Alimentos para Lactentes), the World Breastfeeding Week Campaigns, and the incorporation of health services in the promotion of breastfeeding through the Children's Friend Hospital Initiative (Iniciativa Hospital Amigo da Criança), the network of Human Milk Banks, and the strategies directed to primary healthcare ${ }^{2}$.

The median duration of exclusive breastfeeding has evolved from 1.1 months, in 1996, to 1.4 months, in 2006, while the median duration of breastfeeding has increased from 7.0 months in 1996 to 14.0 months in $2006^{3}$. In the second survey carried out in capital cities of Brazilian states and in the Federal District, in 2008, exclusive breastfeeding was found in $41.0 \%$ of children less than six months old, and breastfeeding (including non-exclusive breastfeeding) was found in $58.7 \%$ of children aged 9 to 12 months - higher than the figures for 1999. In spite of the progress observed, the situation in Brazil is still not yet good, since the World Health Organization $(\mathrm{WHO})^{4}$ considers both exclusive breastfeeding percentages below $50 \%$ and median total breastfeeding times below 18 months to be below the desire standard.

The WHO recommends exclusive breastfeeding for six months, and breastfeeding complemented by other foods for two years or more. It is against the use of bottles and other object with a teat-shaped profile, for their potential interference with optimal breastfeeding practices and for the association between their use and illness or death from diarrheia ${ }^{5}$. However, in the survey taken in 2008 in Brazilian state capital cities and Federal District, it was found that $58.4 \%$ of children aged less than one year used a bottle, and $42.6 \%$ a pacifier ${ }^{4}$.

Continuation of breastfeeding in the second half-year of life is important because absorption of $500 \mathrm{ml}$ of mother's milk per day is capable of providing approximately $75 \%$ of energy needs, $50 \%$ of protein needs, and $95 \%$ of the need for vitamin $\mathrm{A}^{6}$. It also provides immunological protection to the child, reducing the rates of hospital admissions for diarrhea-related illness ${ }^{7}$ and pneumonia ${ }^{8}$. By sucking on the areola region of the mother's breast, the child adopts a posture that is appropriate for breathing through the nose, with the tongue in the proper position, favoring the function of chewing, production of the right sounds in speech and the proper transport of food".

In view of the importance of continued breastfeeding for both mother and child, for public health, and the limited publication of studies on the subject, this article aims to investigate the degree of absence of breastfeeding in the second half-year of life in a municipality of the state of Rio de Janeiro, and also to investigate the factors associated with this practice, especially the use of bottle and pacifier.

\section{Methods}

This is a cross-sectional study, resulting from interviews of people caring for children less than one year old on the subject of feeding habits in the first year of life, during the 2006 National Vaccination Campaign, in the town of Barra Mansa. The study was based on the 'Breastfeeding and Municipalities' ('AMAMUNIC') program, organized by the Health Institute of São Paulo State since 1998, for the purpose of monitoring infant feeding practices ${ }^{10}$.

The sampling plans of this enquiry were prepared by the São Paulo Health Institute (IS/SES/ $\mathrm{SP})$, based on information supplied by the Municipal Health Department of Barra Mansa, relating to the number of vaccination posts in each health district and estimation of the number of children less than one year old that would be vaccinated in each post. These estimates were built based on the spreadsheets of the vaccination campaign of the previous year and the number of children registered with the Basic Healthcare Information System (Sistema de Informação da Atenção Bási$c a$, or SIAB). The municipality of Barra Mansa is in the Central Paraíba River region of Rio de Janeiro State, and has an estimated population of 179,000 , of whom $99 \%$ live in urban areas ${ }^{11}$.

Considering that the children were not uniformly distributed between the vaccination posts (which served conglomerated areas), a lottery 
selection system was adopted in two stages, with probability proportional to the size of conglomerated units. Selection was carried out systematically by random choice in both of two stages: the vaccination points were selected in the first stage, and the children in each post in the second.

The sample developed is considered to be equiprobabilistic or self-weighted, that is to say, it is considered that all the children who went to the vaccination posts during the campaigns have the same probability of belonging to the sample that was arrived at by the lottery method, avoiding the need for subsequent weighting ${ }^{10}$. In 2006 the sample size for the survey in Barra Mansa was calculated at 1,140 children less than one year old. A total of 1,287 mothers or persons responsible for children were interviewed in 36 vaccination posts, and 580 of these children were between the ages of six months and one year. In that year, the vaccination coverage was $96.0 \%$, according to the Epidemiology Sector of the $\mathrm{Mu}$ nicipal Health Department of Barra Mansa. For this present study, all children under the age of six months were excluded, and this sub-sample was sufficient to detect differences of 3\%, with a significance level of $5 \%$ and testing power of $80 \%$, calculated a posteriori. Analysis by age groups has been a usual procedure in studies based on surveys carried out under the AMAMUNIC methodology ${ }^{10,12}$, and in this present study children in the second six months of life were almost $50 \%$ of those less than one year old, tending to support the hypothesis that the age group is faithfully represented in the total sample.

The interviews were carried out by community health agents and students on the undergraduate nursing course, trained by the team of the Women's, Children's and Adolescents' Total Healthcare Program (Programa de Assistência Integral à Saúde da Mulher, Criança e Adolescente, or PAISMCA) of Barra Mansa, under the supervision of the Food and Nutrition Technical Department coordinator. The interviewers were oriented to use the data collection questionnaire in a standardized way when dealing with the infants' mothers or other carers.

For selection of the children in the vaccination queue, the interviewers were oriented about the practice of systematic lottery-choice. Before the questionnaire was applied, mothers were informed about the survey and the non-obligatory character of participation in it. Aiming for standardization of the information necessary for explanation to mothers or carers about the nature of the survey, they were shown a Survey Presen- tation Sheet prior to application of the questionnaire, which they were not obliged to sign, so as not to interfere with the routine of the vaccination activity. The questionnaire was applied only after verbal consent by the person responsible for the child, who had the right to refuse, or to stop the interview, and a guarantee of secrecy of information was given.

The questionnaire used the 'current status' method, reflecting current practices in breastfeeding taking place in the prior 24 hours, and use of pacifier and bottle, according to the WHO recommendations for surveys on breastfeeding $^{5}$. Information was also collected about the social-economic and reproductive profile of the mothers, characteristics of birth, and childcare. These data were tabulated by the PAISMCA project team, generating the database analyzed in this article.

This study was not submitted to the Ethics Committee for assessment in relation to risks to human beings, because it uses a secondary database, in which it is not possible to identify individuals - carers and children, in accordance with Resolution 196/96 ${ }^{13}$. The use of the database was authorized by the Coordinating Office of the Food and Nutrition technical area of the Barra Mansa Municipal Health Department. Initially the profile of the mothers and children aged 6 to 12 months was characterized. The following were used as independent factors: use of bottle: yes/no (reference variable); use of pacifier: yes/no (reference variable); child's carer: mother (reference variable) or other; mother's age: $<20$, 20 to $34,>34$ (reference); type of birth: mother's first birth or otherwise (reference); mother's level of schooling: secondary incomplete, or higher (reference); mother working: yes/no (reference); municipality of residence: Barra Mansa (reference), or other; vaccination location area: rural or urban (reference); financing of birth hospital: private/public (reference); type of birth: caesarean/normal (reference); gender of baby: female/ male (reference); weight at birth: $<2,500 \mathrm{~g} / 2,500 \mathrm{~g}$ of more (reference); baby's age: 6 to 8 months (reference)/9-11 months; any prior hospitalizations: yes/no (reference). The association between each exposure factor and the absence of breastfeeding was ascertained. The outcome was characterized in binary form, where zero equals children who received mother's milk in the last 24 hours (reference); and 1 equals children who did not receive it.

A univariate analysis was carried out to ascertain the distribution of the independent variables 
and of the outcome under investigation, followed by a bivariate analysis between each independent variable and the outcome. Chi-squared hypothesis tests were carried out and gross prevalence ratios (PRs) were obtained, with their respective confidence intervals of 95\% (CI95\%). Independent variables, which in the bivariate analysis were shown to be associated to the outcome with an observed significance level of $20 \%$ or less in the chi-squared test ( $p$-value $\geq 0.20$ ), were selected for the multiple analysis.

The adjusted prevalence ratios were obtained by a Poisson regression model, with robust variance, due to the high prevalence of the outcome ${ }^{14}$. The final model, used to estimate measures of association with their respective confidence intervals of $95 \%$, comprised the various independent variables that achieved an observed significance level less than or equal to $5 \%$ ( $\mathrm{p}$-value $\geq 0.05$ ). The SPSS 17.0 software was used for the data analysis.

\section{Results}

$40.0 \%$ of the children in the second six months of their lives were not being breastfed. The practice of breastfeeding declined after 10 months of life (Figure 1). The greater part of those interviewed were mothers who were accompanying their children in the vaccination queue. More than half of the mothers had incomplete secondary education, and one quarter of them were working. Almost two-thirds of the mothers had their children in a private hospital and were submitted to a caesarean birth. Almost half the babies used a pacifier, and $57.3 \%$ used a bottle (Table 1 ).

In the bivariate analysis (Table 2), the use of pacifier and bottle, the child not being accompanied by the mother, the mother's age being up to 34 years, the mother working, it being the mother's first child, the child being born in a private hospital, low birth weight, the child being 9-11 months old, and prior hospitalization for some disease were shown to be associated with absence of breastfeeding, while the mother having secondary education incomplete, or a lower educational level, was associated with the presence of breastfeeding. In the multiple model, use of pacifier $(\mathrm{PR}=3.245)$, use of bottle $(\mathrm{PR}=1.605)$, the child not being accompanied by the mother ( $\mathrm{PR}$ $=1.324)$, lower mother's schooling $(\mathrm{PR}=0.826)$, low birth weight $(\mathrm{PR}=1.488)$, and increasing age of the child, in days $(\mathrm{PR}=1.004)$ were associated

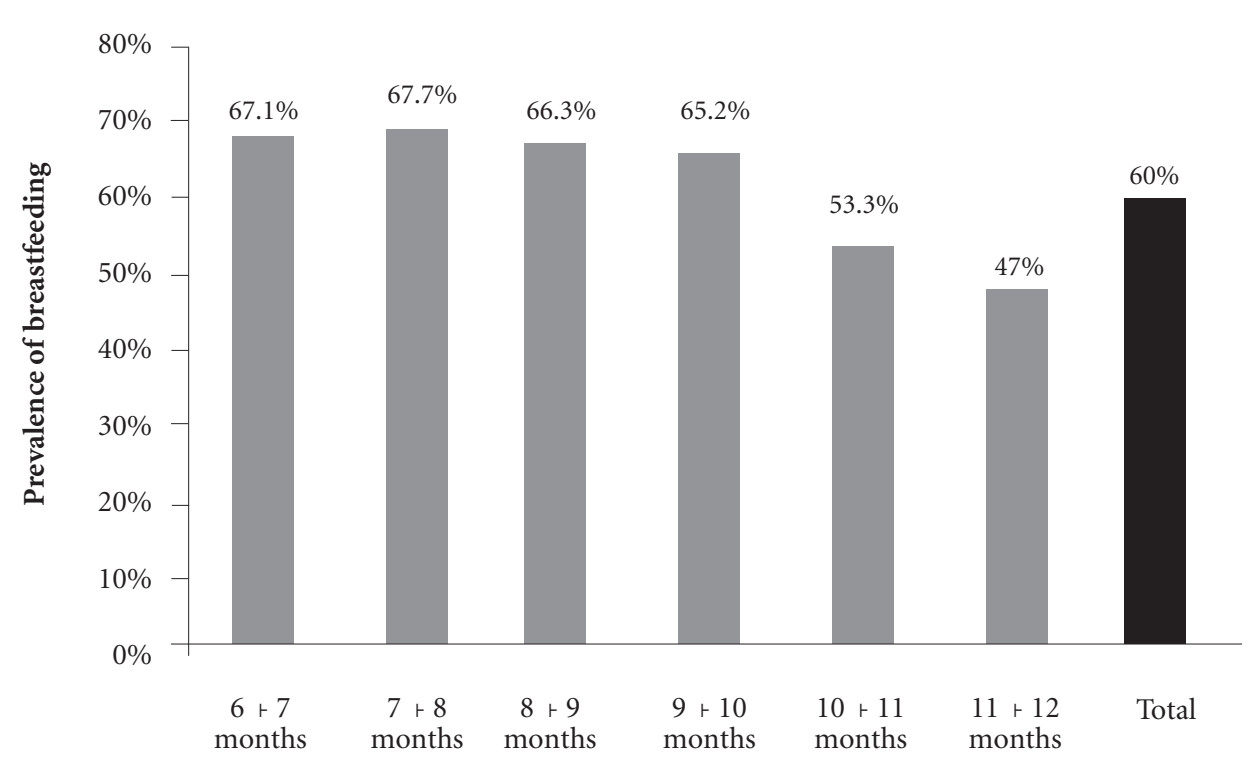

Age in months

Figure 1. Prevalence of breastfeeding in the second half-year of life. Municipality of Barra Mansa, 2006. 
with the child not breastfeeding in the second six months of life (Table 3 ).

Table 1. Maternal social-demographic and reproductive characteristics and characteristics of birth and care of the child in the second half-year of life - Municipality of Barra Mansa, 2006.

\begin{tabular}{|c|c|c|}
\hline Variable & $\mathbf{n}$ & $\%$ \\
\hline \multicolumn{3}{|l|}{ Person accompanying the child } \\
\hline Mother & 484 & 83.4 \\
\hline Other & 96 & 16.6 \\
\hline \multicolumn{3}{|l|}{ Mother's age } \\
\hline$<20$ years & 72 & 12.4 \\
\hline $20-34$ & 425 & 73.3 \\
\hline$>34$ & 68 & 11.7 \\
\hline \multicolumn{3}{|l|}{ Level of education } \\
\hline Up to secondary incomplete & 341 & 61.0 \\
\hline Secondary completed or higher & 218 & 39.0 \\
\hline \multicolumn{3}{|l|}{ Mother has paid employment } \\
\hline Yes & 145 & 25.1 \\
\hline No & 433 & 74.9 \\
\hline \multicolumn{3}{|l|}{ Municipality of residence } \\
\hline Barra Mansa & 556 & 95.9 \\
\hline Other municipality & 24 & 4.1 \\
\hline \multicolumn{3}{|l|}{ Area of residence } \\
\hline Urban & 548 & 94.5 \\
\hline Rural & 32 & 5.5 \\
\hline \multicolumn{3}{|l|}{ First or later child } \\
\hline First & 302 & 52.1 \\
\hline Second or later & 278 & 47.9 \\
\hline \multicolumn{3}{|l|}{ Birth hospital: financing } \\
\hline Private & 354 & 62.2 \\
\hline Public & 215 & 37.8 \\
\hline \multicolumn{3}{|l|}{ Type of birth } \\
\hline Normal & 199 & 34.4 \\
\hline Caesarian & 380 & 65.6 \\
\hline \multicolumn{3}{|l|}{ Gender of child } \\
\hline Male & 296 & 51.0 \\
\hline Female & 284 & 49.0 \\
\hline \multicolumn{3}{|l|}{ Birth weight } \\
\hline$<2500 \mathrm{~g}$ & 44 & 7.7 \\
\hline $2500 \mathrm{~g}$ or more & 527 & 92.3 \\
\hline \multicolumn{3}{|l|}{ Child's age } \\
\hline 6-8 months & 265 & 45.7 \\
\hline 9-11 months & 315 & 54.3 \\
\hline \multicolumn{3}{|l|}{ Prior hospitalization } \\
\hline Yes & 42 & 7.3 \\
\hline No & 531 & 92.7 \\
\hline \multicolumn{3}{|l|}{ Use of pacifier } \\
\hline Yes & 274 & 47.2 \\
\hline No & 306 & 52.8 \\
\hline \multicolumn{3}{|l|}{ Use of feeding bottle } \\
\hline Yes & 331 & 57.3 \\
\hline No & 247 & 42.7 \\
\hline
\end{tabular}

\section{Discussion}

The patterns of breastfeeding observed in the second six months of life in Barra Mansa, in 2006, were not yet on a level with those specified by the World Health Organization, since $40 \%$ of the children were not being breastfed. The principal factor associated with absence of breastfeeding was use of a pacifier, followed by use of a bottle, both these practices being counter-indicated by the World Health Organization ${ }^{5}$. Also, low birth weight, the child not being accompanied by the mother, higher level of the mother's schooling and increasing age of the child, in days, were associated with lower occurrence of breastfeeding.

In spite of the importance for the child's health of breastfeeding in the second half-year of life ${ }^{6-8}$, the practice of ceasing breastfeeding in this stage of life, and the factors determining it, have been little investigated. The occurrence found in this study is close to that found in other studies, also made in 2006, in vaccination campaigns in the city of Rio de Janeiro, where $38.2 \%$ of children aged six months to one year had already stopped breastfeeding ${ }^{12}$. In the city of Volta Redonda, in Rio de Janeiro State, the percentage was $36.2 \%{ }^{15}$, and in Salvador, Bahia, $42.6 \%{ }^{16}$. In other scenarios, more adverse results were found. In Campinas, São Paulo State, in the 2001 vaccination campaign, $62.0 \%$ of children in the second six months of life were already not breastfeeding ${ }^{17}$. In studies made in 2005, in São Paulo, Recife and Curitiba, $55.4 \%$ of children aged 6 to 12 months were not breastfeeding ${ }^{18}$, a similar percentage to that found in 16 municipalities of Paraíba State, where the figure was $54.8 \%{ }^{19}$.

Of the factors investigated, use of the pacifier was the one most strongly associated with absence of breastfeeding in the second six months of life, this outcome being three times more frequent among children using a pacifier - which serves to re-emphasize the importance of discouraging its use. This finding was consistent with those in other Brazilian studies investigating the factors associated with this outcome in children less than one year old ${ }^{20-24}$. The use of a pacifier is still a very widespread cultural habit among Brazilian children and is prejudicial to breastfeeding because it reduces the frequency of breastfeeding itself, reducing the mother's output of milk, and can lead to failure to identify the nipple. Use of a pacifier can also reflect difficulties for the mother, such as anxiety, insecurity, and problems in handling breastfeeding ${ }^{25}$. 
Table 2. Prevalence and prevalence ratio of absence of breastfeeding in the second half-year of life analyzed by: mothers' social-demographic and reproductive characteristics, and characteristics of child's birth and healthcare - Municipality of Barra Mansa, 2006.

\begin{tabular}{|c|c|c|c|c|}
\hline Characteristics & Prevalence & Gros PR & CI 95\% & p-value \\
\hline \multicolumn{5}{|l|}{ Use of pacifier } \\
\hline Yes & $65.0 \%$ & 3.68 & $2.846-4.761$ & $<0.001$ \\
\hline No & $17.6 \%$ & 1 & & \\
\hline \multicolumn{5}{|l|}{ Use of feeding bottle } \\
\hline Yes & $51.4 \%$ & 2.11 & $1.657-2.698$ & $<0.001$ \\
\hline No & $24.3 \%$ & 1 & & \\
\hline \multicolumn{5}{|l|}{ Person accompanying the child } \\
\hline Mother & $36.8 \%$ & 1 & & \\
\hline Other & $56.3 \%$ & 1.53 & $1.238-1.890$ & $<0.001$ \\
\hline \multicolumn{5}{|l|}{ Mother's age } \\
\hline$<20$ years & $43.1 \%$ & 1.39 & $0.894-2.173$ & 0.142 \\
\hline $20-34$ & $39.5 \%$ & 1.28 & $0.880-1.861$ & 0.196 \\
\hline$>34$ & $30.9 \%$ & 1 & & \\
\hline \multicolumn{5}{|l|}{ Mother's level of education } \\
\hline Up to secondary incomplete & $34.3 \%$ & 0.73 & $0.593-0.890$ & 0.002 \\
\hline Secondary complete or higher & $47.2 \%$ & 1 & & \\
\hline \multicolumn{5}{|l|}{ Mother has paid employment } \\
\hline Yes & $55.9 \%$ & 1.60 & $1.320-1.944$ & $<0.001$ \\
\hline No & $34.9 \%$ & 1 & & \\
\hline \multicolumn{5}{|l|}{ Location of residence } \\
\hline Barra Mansa & $40.3 \%$ & 1 & & \\
\hline Other municipality & $33.3 \%$ & 0.83 & $0.466-1.470$ & 0.518 \\
\hline \multicolumn{5}{|l|}{ Place of vaccination } \\
\hline Urban area & $40.5 \%$ & 1 & & \\
\hline Rural area & $31.3 \%$ & 0.77 & $0.457-1.302$ & 0.331 \\
\hline \multicolumn{5}{|l|}{ First or later child } \\
\hline First & $43.0 \%$ & 1.17 & $0.959-1.435$ & 0.121 \\
\hline Second or later & $36.7 \%$ & 1 & & \\
\hline \multicolumn{5}{|l|}{ Birth hospital } \\
\hline SUS & $34.9 \%$ & 1 & & \\
\hline Private & $42.1 \%$ & 1.21 & $0.969-1.503$ & 0.094 \\
\hline \multicolumn{5}{|l|}{ Type of birth } \\
\hline Normal & $36.7 \%$ & 1 & & \\
\hline Caesarian & $41.8 \%$ & 1.14 & $0.918-1.418$ & 0.236 \\
\hline \multicolumn{5}{|l|}{ Gender of child } \\
\hline Female & $38.0 \%$ & 0.91 & $0.743-1.109$ & 0.343 \\
\hline Male & $41.9 \%$ & 1 & & \\
\hline \multicolumn{5}{|l|}{ Birth weight } \\
\hline$<2500 \mathrm{~g}$ & $65.9 \%$ & 1.73 & $1.361-2.194$ & $<0.001$ \\
\hline $2500 \mathrm{~g}$ or more & $38.1 \%$ & 1 & & \\
\hline \multicolumn{5}{|l|}{ Child's age } \\
\hline 6-8 months & $32.8 \%$ & 1 & & \\
\hline 9-11 months & $46.0 \%$ & 1.25 & $1.090-1.421$ & 0.001 \\
\hline \multicolumn{5}{|l|}{ Prior hospitalization } \\
\hline Yes & $50.0 \%$ & 1.27 & $0.926-1.759$ & 0.135 \\
\hline No & $39.2 \%$ & 1 & & \\
\hline
\end{tabular}

The proportion of children not breastfed was $61 \%$ higher in children that used a bottle. In the state of Piauí, the probability of not being cur- rently breastfed was six times higher ${ }^{23}$, and in São Leopoldo, in the state of Rio Grande do Sul, the probability was double, for children who used 
Table 3. Adjusted prevalence ratio of absence of breastfeeding in the second half-year of life analyzed by: mothers' socio-demographic and reproductive characteristics, and characteristics of child's birth and healthcare, Municipality of Barra Mansa, 2006.

\begin{tabular}{lccc}
\hline \multicolumn{1}{c}{ Characteristics } & Adjusted PR & CI 95\% & p-value \\
\hline $\begin{array}{l}\text { Use of pacifier } \\
\quad \text { Yes }\end{array}$ & 3.245 & $2.490-4.228$ & $<0.001$ \\
$\quad$ No & 1 & & \\
Use of feeding bottle & 1.605 & $1.273-2.023$ & $<0.001$ \\
$\quad$ Yes & 1 & & \\
$\quad$ No & 1 & & 0.007 \\
Person accompanying the child & 1.324 & $1.080-1.622$ & \\
$\quad \begin{array}{l}\text { Mother } \\
\text { Other }\end{array}$ & 0.825 & $0.689-0.990$ & \\
Mother's level of education & 1 & & \\
$\quad \begin{array}{l}\text { Up to secondary incomplete } \\
\text { Secondary complete or higher }\end{array}$ & 1.453 & $1.162-1.817$ & 0.001 \\
Birth weight & 1 & & $<0.001$ \\
$\quad<2500$ g & 1.004 & $1.002-1.006$ & \\
$\quad$ 2500g or more & & & \\
Age of child in days & & & \\
\hline
\end{tabular}

a bottle in the first month of life ${ }^{20}$. However, in Itapira, São Paulo State, in 1999, the use of the bottle did not show any significant association after adjustment for other factors, such as use of a pacifier ${ }^{21}$. Mistaken interpretation of the baby's crying can lead to introduction of artificial feeding using a bottle, leading to reduced suction at the breast and, consequently, lower production of mother's milk ${ }^{26}$. These are possible explanations for the association found between the bottle and absence of breastfeeding.

Low birth weight was another factor associated with the outcome in this study, increasing the absence of breastfeeding in the second half-year of life by $45.0 \%$. This was consistent with the result found in Itapira (São Paulo State), where absence of breastfeeding in children under one year old was almost three times higher in children born with low weight ${ }^{21}$. A study in Londrina, in the State of Paraná, with children under one year old, did not show the effect of this variable, but made and adjustment for birth weight ${ }^{22}$. This association between low weight and non-breastfeeding may possibly be due to inefficient suction and the longer period of hospitalization of babies with low weight, which can lead to low production of mother's milk and reduce breastfeeding over the child's first year of life.

A mother's level of schooling being lower than complete secondary education reduced the occurrence of breastfeeding by $17 \%$. A nationwide survey in 2006 found the same pattern: the median duration of breastfeeding was 21 months for mothers with less than four years' schooling, and 13.1 months for those with nine years or more ${ }^{3}$.

With each 10 days of the child's life, the occurrence of breastfeeding was reduced by $4.0 \%$. Other Brazilian studies of babies less than one year old made an adjustment for the child's age in days, but did not report the effect of this variable ${ }^{10,22}$. In a study in East Timor with children of less than one year, the probability of being currently breastfed fell by $23 \%$ for each month of the child's life ${ }^{27}$.

The fact of the child not coming to be vaccinated accompanied by her mother was associated with an absence of breastfeeding. It is supposed that the mother who breastfeeds may have more difficulty in allowing another person to accompany the child to vaccination, not only because of the attachment, but also because she can offer the breast as a calming factor after vaccination. This variable needs to be better understood, because various Brazilian studies have used surveys by AMAMUNIC as a database, but the person accompanying the child has not been a factor that was investigated.

Surveys taken in vaccination campaigns allow information to be gathered in a short time and with low cost, but can have limitations. Since it was a questionnaire survey, it was not possible to establish a temporal relation of causality be- 
tween most of the variables investigated and the outcome. There is a possible bias in selection, because children who are ill may have not attended the vaccination campaign, since the campaign's coverage in Barra Mansa, in 2006, was 96\%. Another limitation would be that in the present study some variables that were shown to be associated with absence of breastfeeding in the first years of life in international studies were unable to be explored, because they were not present in the database of this study, such as the number of follow-up visits after birth ${ }^{28}$, marital status, and mother's ethnicity ${ }^{29}$. As a positive point, we consider that the majority of the associations found can be generalized to the Brazilian context, because they are not specificities of Barra Mansa.

The municipality of Barra Mansa has been carrying out actions to promote, protect and support breastfeeding for at least 10 years, both in its Family Health Strategy units and also in its basic healthcare units, where health professionals are trained for these actions by the methodology of the "Pro-Breastfeeding Basic Healthcare Unit Initiative" (Iniciativa Unidade Básica Amiga da Ama- mentação $)^{30}$. Although these actions are achieving progress in the practice of exclusive breastfeeding $^{31}$, it can be noted that in 2006 the recommendations of the World Health Organization and of the Brazilian Health Ministry were not yet being fully obeyed. The actions taken in basic healthcare need to be complemented by others to be put in place in hospitals, such as the Children's Friend Hospital Initiative ${ }^{2}$, and also in other sectors, such as education and social protection.

It is, thus, recommended that the public policies currently practiced in promotion, protection and support of breastfeeding, and discouragement for the use of artifacts that are potentially prejudicial to breastfeeding, should be intensified, and articulated in an inter-sector action, in which the populations identified as being at risk in this present study should be given priority. Since it is a subject that has been little explored, further studies are recommended on the predictive factors for breastfeeding in the second six months of life, so as to contribute to the scientific knowledge available in this area, and the improvement of public policies.

\section{Collaborations}

RR Rigotti, MIC Oliveira and CS Boccolini participated equally in all the stages of preparation of the article. 


\section{References}

1. Newburg DS. Neonatal protection by an innate immune system of human milk consisting of oligosaccharides and glycans. J Anim Sci 2009; 87(Supl. 13):26-34.

2. Rea MF. Reflexões sobre a amamentação no Brasil: de como passamos a 10 meses de duração. Cad Saude Publica 2003; 19(Supl. 1):537-545.

3. Brasil. Ministério da Saúde (MS). Centro Brasileiro de Análise e Planejamento. Pesquisa Nacional de Demografia e Saúde da Criança e da Mulher - PNDS 2006: dimensões do processo reprodutivo e da saúde da criança. Brasília: Editora do Ministério da Saúde; 2009.

4. Brasil. Ministério da Saúde (MS). II Pesquisa de Prevalência de Aleitamento Materno nas Capitais Brasileiras e Distrito Federal. Brasília: Editora do Ministério da Saúde; 2009.

5. World Health Organization (WHO). Dept. of Child and Adolescent Health and Development. Indicators for assessing infant and young child feeding practices: conclusions of a consensus meeting held 6-8 November 2007 in Washington D.C., USA. Geneva: WHO; 2008.

6. Organização Mundial de Saúde (OMS). Evidencias científicas dos dez passos para o sucesso do aleitamento materno. Brasília: Organização Pan-Americana de Saúde (OPAS); 2001.

7. Boccolini CS, Boccolini PM. Relação entre aleitamento materno e internações por doenças diarreicas nas crianças com menos de um ano de vida nas Capitais Brasileiras e Distrito Federal, 2008. Epidemiol Serv Saúde 2011; 20(1):19-26.

8. Boccolini CS, Carvalho ML, Oliveira MIC, Boccolini PM. O papel do aleitamento materno na redução das hospitalizações por pneumonia em crianças brasileiras menores de 1 ano. J Pediatr (RJ) 2011; 87(5):399-404.

9. Neiva FCB, Cattoni DM, Ramos JLA, Issler H. Desmame precoce: implicações para o desenvolvimento motororal. J Pediatr (RJ) 2003; 79(1):7-12.

10. Venancio SI, Escuder MML, Kitoko P, Rea MF, Monteiro CA. Frequência e determinantes do aleitamento materno em municípios do Estado de São Paulo. Rev Saude Publica 2002; 36(3):313-318.

11. Instituto Brasileiro de Geografia e Estatística (IBGE). IBGE cidades. [acessado 2014 abr 23]. Disponível em: http://www.cidades.ibge.gov.br

12. Coutinho LMS, Scazufca M, Menezes PR. Métodos para estimar razão de prevalência em estudos de corte transversal. Rev Saude Publica 2008; 42(6):992-998.

13. Brasil. Ministério da Saúde (MS). Conselho Nacional de Saúde. Resolução no 196 de 10 de outubro de 1996. Diretrizes e Normas Regulamentadoras de Pesquisas Envolvendo Seres Humanos. Diário Oficial da União 1996; 16 out.

14. Castro IRR, Engstrom EM, Cardoso LO, Damião JJ, Rito RVFV, Gomes MASM. Tendência Temporal da Amamentação na cidade do Rio de Janeiro: 1996 a 2006. Rev Saude Publica 2009; 43(6):1021-1029.

15. Cruz MCC, Almeida JAG, Engstrom EM. Práticas alimentares no primeiro ano de vida de filhos de adolescentes. Rev Nutr Campinas 2010; 23(2):201-210.
16. Oliveira LPM, Assis AMO, Gomes GSS, Prado MS, Barreto ML. Duração do aleitamento materno, regime alimentar e fatores associados segundo condições de vida em Salvador, BA. Cad Saude Publica 2005; 21(5):1519-1530.

17. Cecchetti DFA, Moura EC. Prevalência do aleitamento materno na região noroeste de Campinas, São Paulo, Brasil, 2001. Rev Nutr Campinas 2005; 18(2):201-208.

18. Caetano MC, Ortiz TT, da Silva SG, de Souza FI, Sarni RO. Complementary feeding: inappropriate practices in infants. J Pediatr (Rio J) 2010; 86(3):196-201.

19. Palmeira PA, Santos SMC, Vianna RPT. Prática alimentar entre crianças menores de dois anos de idade residentes em municípios do semiárido do Estado da Paraíba. Rev Nutr Campinas 2011; 24(4):553-563.

20. Feldens CA, Vitolo MR, Rauber F, Cruz LN, Hilgert JB. Risk Factors for Discontinuing Brestfeeding in Southern Brazil: A Survival Analysis. Matern Child Health J 2012; 16(6):1257-1265.

21. Audi CAF, Correa MAS, Latorre MRDO. Alimentos complementares e fatores associados ao aleitamento materno e ao aleitamento materno exclusivo em lactentes até 12 meses de vida em Itapira, São Paulo. Rev Bras Saúde Matern Infant 2003; 3(1):85-93.

22. Vannuchi MTO, Thomson Z, Escuder MM, Vezozzo KMK, Castro LMCP, Oliveira MMB, Venâncio SI. Perfil do aleitamento materno em menores de um ano no município de Londrina, Paraná. Rev Bras Matern Infant 2005; 5(2):155-162.

23. Ramos CV, Almeida JAG, Alberto NSMC, Teles JBM, Saldiva SRDM. Diagnóstico da situação do aleitamento materno no Estado do Piauí, Brasil. Cad Saude Publica 2008; 24(8):1753-1762.

24. França GVA, Brunken GS, Silva SM, Escuder MM, Venancio SI. Determinantes da amamentação no primeiro ano de vida em Cuiabá, Mato Grosso. Rev Saude Publica 2007; 41(5):711-718.

25. Jaafar SH, Jahanfar S, Angolkar M, Ho JJ. Effect of restricted pacifier use in breastfeeding term infants for increasing duration of breastfeeding. Cochrane Database Syst Rev 2012; 7:CD007202.

26. Giugliani ER, Rocha VL, Neves JM, Polanczyk CA, Seffrin CF, Susin LO. Conhecimentos maternos em amamentação e fatores associados. J Pediatr (RJ) 1995; 71(2):77-81.

27. Senarath U, Dibley MJ, Agho KE. Breastfeeding practices and associated factors among children under 24 months of age in Timor-Leste. European J Clin Nutr 2007; 61(3):387-397.

28. Senarath U, Siriwardena I, Godakandage SSP, Jayawickrama H, Fernando DN, Dibley MJ. Determinants of breastfeeding practices: an analysis of the Sri Lanka Demographic and Health Survey 2006-2007. Matern and Child Nutr 2012; 8(3):315-329. 
29. Kimani-Murage EWK, Madise NJ, Fotso JC, Kyobutungi C, Mutua MK, Gitau TM, Yatich N. Patterns and determinants of breastfeeding and complementary feeding practices in urban informal settlements, Nairobi Kenya. BMC Public Health 2011; 11:396.

30. Oliveira MIC, Camacho LAB, Souza IEO. Promoção, proteção e apoio à amamentação na atenção primária à saúde no Estado do Rio de Janeiro, Brasil: uma política de saúde pública baseada em evidência. Cad Saude Publica 2005; 21(6):1901-1910.

31. Alves ALN, Oliveira MIC, Moraes JR. Iniciativa Unidade Básica Amiga da Amamentação e sua relação com o aleitamento materno exclusivo. Rev Saude Publica 2013; 47(6):1130-1140.

Article submitted 03/19/2014

Approved 09/10/2014

Final version submitted 09/23/2014 